\title{
SPEAKING LEARNING STRATEGIES EMPLOYED BY ENGLISH-MAJORED SOPHOMORES AT COLLEGE OF FOREIGN ECONOMIC RELATIONS
}

\author{
Truong Minh $\mathrm{Hoa}^{1 *}$, Phan Thi Mien Thao ${ }^{2}$ \\ 1. Nguyen Tat Thanh University, \\ 300A Nguyen Tat Thanh Street, Ward 13, District 4, Ho Chi Minh City, Viet Nam \\ 2. New Oriental Foreign Language School \\ 4/34 Quang Trung Street, Thoi Tam Thon Ward, Hocmon District Ho Chi Minh City, Vietnam
}

Received 09 January 2020

Revised 31 March 2020; Accepted 30 May 2020

\begin{abstract}
The increasing demand for good communicative skills in a globalized society activates English speaking learning around the world. Specific to the Vietnamese context, after many years of being much exposed to English, most of tertiary students still find it difficult to communicate effectively in realistic situations since they have not yet possessed effective speaking learning strategies (Richards, 2002; Rababa'h, 2005). This study aimed at exploring speaking learning strategies employed by 82 English-majored sophomores at College of Foreign Economic Relations (COFER), Ho Chi Minh City, Vietnam. Mixed-methods design was used for collecting data, involving the two research instruments: a questionnaire and a semi-structured interview. While quantitative data obtained from the questionnaire were analyzed by SPSS 22.0, interview results were thematically analyzed. The findings of the study indicated that the majority of the English-majored sophomores usually utilized both direct and indirect strategies. The most frequently used strategies consisted of structuring or planning of ideas and language input, using dictionary for vocabulary learning, compensating for linguistic limitations by code-switching, nonverbal forms, synonyms, paying attention, deeply breathing, and asking for clarification. However, activating prior knowledge, self-training language input, self-evaluating speaking performance were less frequently used among many students. For implications, teachers should make students aware of the importance of background knowledge and create more opportunities for students to utilize their prior knowledge in their speaking performance, encourage them to frequently practice their listening skills and pronunciation to improve speech quality, and guide them how to assess their own speaking performance.
\end{abstract}

Keywords: speaking learning strategies, English-majored, sophomores, COFER

\section{Introduction}

\subsection{Background of the Study}

The increasing demand for good communicative skills in a globalized society activates English speaking learning around

* Corresponding author: Tel.: 84-984430699

Email: ngutngonnguhoc91@gmail.com the world. English is spoken all over the world, that is, one can communicate easily with both native speakers of English and nonnative ones if she/he is proficient in English. By virtue of this, being competent in oral communication is a strong desire of all English learners. And speaking is a fundamental skill that learners need to master in order to communicate effectively. Phan (2014) shows 
that English is considered a "passport" to integrate with the world. Therefore, the EFL learners in general and the students at COFER in particular are also aware of the importance of English speaking learning. According to Brown and Yule (1983), in the process of language learning, speaking is highly evaluated to be important, yet the most difficult of the four skills. However, many language learners, even after several years of studying English, still find it very difficult to speak effectively. Brown (2001) believes that colloquial language, reduced forms, performance variables, redundancy clusters, rate of delivery, stress, rhythm and intonation are among the characteristics of speaking that contribute to the difficulty of this skill. Moreover, in order for language learners to manage oral communication, they need to produce connected speech, have interaction ability, speak in different contexts, develop a balance between accuracy and fluency, and talk about unfamiliar issues based on their knowledge (Lindsay \& Knight, 2006). Especially, one of various possible reasons for speaking incompetency among EFL learners is that students have not yet handled their speaking learning strategies effectively. It is also inferred that learners can improve communicative proficiency by developing an ability to use specific speaking strategies that enable them to compensate for their target language deficiency (e.g. Richards \& Renandya, 2002; Mahripah, 2014).

Language learning strategies have been the heart of foreign language education, attracting an ample of language theorists for the last few decades (e.g. Hedge, 2000; Richards \& Renandya, 2002; López, 2011; Mahripah, 2014). The aspects of learning strategies have been extensively concerned to get deep insight. More recently, the focus of the research studies has been specified to each language skill, and speaking is an illustration (e.g. Rachmawati, 2012; Gani, Fajrina \& Hanifa, 2015; Eskandari, Behjat \& Kargar, 2015). Speaking strategies help students become more strategic and active in oral productions and rescue them so that they can overcome speaking problems such as linguistic barriers or lack of ideas (Oxford, 1990; O'Malley \& Chamot; 1990; Dörnyei \& Scott, 1995). The verbal and non-verbal strategies (e.g. verbal circumlocution, clarification, non-verbal gestures) may be exerted to compensate for a breakdown in communication or for unknown words/topics, and they may be used to yield effective communication.

In this domain of speaking skill, many studies (e.g. Rachmawati, 2012; Gani, Fajrina \& Hanifa, 2015; Eskandari, Behjat \& Kargar, 2015) have been conducted on the theoretical bases of Oxford's (1990) Strategy Inventory for Language Learning (SILL). O'Malley and Chamot (1990) assert that speaking strategies benefit language learners "in negotiating meaning where either linguistic structures or sociolinguistic rules are not shared between a second language learner and a speaker of the target language" (p. 43). The primary goal for any language learners is that they are able to use the target language for their oral communication, and finally become a competent speaker. Accordingly, Hedge (2000) convinces that a competent speaker is the person who can use speaking strategies effectively to compensate for speaking problems and to maintain his stream of verbal messages. Alternatively stating, knowing and utilizing speaking learning strategies is of utmost importance to students for their oral language development.

In brief, speaking strategies are essential because they sufficiently provide foreign language learners with valuable tools to communicate in the target language in diverse contextual situations and help them to survive a multiplicity of speaking problems. Put it differently, speaking learning strategies become vital to develop students' language ability in order for them to be more selfsufficient and active in their own learning process. 


\subsection{Problem statement}

In reality, there have been more and more communication courses in Vietnam held to respond to leaners' need of improving English communicative competence. However, many Vietnamese learners have still found it difficult to speak English fluently and accurately. After many years of being exposed to English in secondary and high schools, and even at tertiary level, many of them still cannot perform a simple and short conversation in English due to a multitude of factors (Than, 2019; Truong, 2019). Richards (2002) labels several problems faced by poor learners in their English speaking learning. For example, 1) students cannot sustain long conversations or keep the interaction going; 2) students often encounter communication breakdowns and misunderstandings; 3) students' lack of vocabulary and language structures negatively impacts their oral production of ideas; 4) and students' lack of effective communication strategies. Tallying Richards' ideas (2002), Rababa'h (2005) adds one more factor that hinders English speaking ability among EFL learners, that is, inadequate strategic competence and communication competence. In other words, they are deficient in being aware of and applying speaking strategies to facilitate their oral production.

In order to reduce speaking problems and enhance oral performance, language learners need to manipulate particular speaking learning strategies and use them appropriately. Indeed, it is obvious that learners can improve their speaking ability by developing learning strategies that help them to be more strategic and flexible in overcoming speaking problems (Nakatani, 2005). In the same line, there is a positive relationship between learning strategies and students' proficiency level (Hismanoglu, 2000; Anderson, 2003). The greater variety and number of learning strategies students employ, the more language proficient they would be. In general, Chamot (2004) claims that learning strategies contribute to the considerable improvement on the less successful learners' speaking performance. Given the positive impact of speaking learning strategies and the possible speaking problems, the researchers were urged to discover how the EFL second-year students at COFER used speaking strategies during their speaking learning.

\subsection{Research questions}

Accordingly, the research paper formulated one research question as follows: How do the English-majored sophomores at COFER use speaking strategies for their speaking learning?

\section{Literature review}

\subsection{Definition and importance of speaking skill}

Each expert has yielded different ways of defining speaking skill from another. Thornbury (2005) defines that speaking is an activity in real life that is carried out by speaker to express his/ her ideas to interact with interlocutors. To be more specific, according to Nunan (1991), speaking refers to the ability to express a sequence of ideas or to produce utterances fluently. Emphasizing the function of speaking skill, it is about making people understand speaker's feeling and ideas by speaking out the language (Cameron, 2001). Likewise, Kayi (2006) attributes speaking to the process of erecting and dispensing meaning through the manipulation of verbal and nonverbal modes in a multitude of contexts. In summary, speaking is an activity in which the speaker produces utterances (Nunan, 1991) through the use of verbal and nonverbal forms (Kayi, 2006) to express ideas 
in order to exchange information, so the other interlocutor understands what the speaker wants to convey (Cameron, 2001; Thornbury, 2005).

In leaning language, it is rather uneasy to make a conclusion on the most important skill among listening, speaking, reading and writing. However, speaking is deemed to be the closest to the goal of language teaching; that is, speaking performance. Ur (1996) considers that of all the four skills, speaking seems intuitively the most important one because the ability to speak skillfully provides the learners a favorable condition to establish and maintain relationships, to negotiate with others. In specific, Carnegie (1977) assumes that business, social, and personal satisfaction depend heavily on people's ability to communicate to others about their identities, desires and beliefs. Nunan (1991) views good speaking performance as the most important aspect of acquiring a foreign language, which is assessed by the ability to sustain a conversation in the target language. In short, speaking plays a crucial part in social life and is a dispensable skill for any language learner. strategies.

\subsection{Definition and categories of speaking strategies}

Speaking strategies are referred to as "communicative strategies, communication strategies, conversation skills or oral communication strategies, used by students to solve any communication problem when speaking in English" (Lopéz, 2011, p. 3). A competent speaker knows how to make use of speaking strategies, which "come into play when learners are unable to express what they want to say because they lack the resources to do so successfully" (Hedge, 2000, p. 52).

In principle, Oxford (1990) differentiates language learning strategies into six groups, namely i) memory strategies, ii) cognitive strategies, iii) compensation strategies, iv) affective strategies, v) metacognitive strategies, and (vi) social strategies. These six strategy groups are categorized into two major classes, namely direct strategies and indirect strategies (see Table 1). Direct strategies consist of memory strategies, cognitive strategies and compensation strategies, while indirect strategies comprise metacognitive strategies, affective strategies and social

Table 1. Oxford's Language Learning Strategy Scheme (1990, pp. 18-21)

\begin{tabular}{ll}
\hline Language Learning Strategies & Description \\
\hline Memory strategies & "Creating links mentally, applying sounds and images, reviewing well". \\
\hline Cognitive strategies & $\begin{array}{l}\text { "Practicing, reviewing and sending messages, analyzing and } \\
\text { reasoning, creating structure for input and output". }\end{array}$ \\
\hline Compensation strategies & $\begin{array}{l}\text { "Guessing intelligently, and overcoming limitations in writing, } \\
\text { speaking". }\end{array}$ \\
\hline Metacognitive strategies & $\begin{array}{l}\text { "Centering one's learning, planning and arranging one's learning, } \\
\text { evaluating one's learning". }\end{array}$ \\
\hline Affective strategies & "Lowering one's anxiety, encouraging oneself, and taking one's \\
& emotional temperature". \\
\hline Social strategies & "Asking questions, cooperating with others and empathizing with \\
& others".
\end{tabular}


Besides, the taxonomy of Dörnyei and Scott (1995) not only refers to strategic behaviors, but also involves three main categories, namely direct strategies, indirect strategies and interactional strategies. This scheme is presented in Table 2.

Table 2. Dörnyei and Scott' (1995) Taxonomy of Speaking Strategies

\begin{tabular}{ll}
\hline Categories & Strategic speaking behaviors \\
\hline Direct strategies & $\begin{array}{l}\text { Message abandonment; reduction; replacement; circumlocution; restructuring; } \\
\text { code switching; self-repair; self-rephrasing }\end{array}$ \\
\hline Indirect strategies & Verbal strategy markers, stimulating understanding, repetition \\
\hline Interactional strategies & $\begin{array}{l}\text { Requesting clarification; requesting repetition; requesting confirmation; } \\
\text { inference; expressing non-understanding, understanding check; own-accuracy } \\
\text { check, asking for assistance }\end{array}$ \\
\hline
\end{tabular}

As can be seen from Table 1 and Table 2, Dörnyei and Scott' (1995) direct strategies refer to the use of an alternative method, which is more manageable and self-contained to convey the intended meaning. Oxford's (1990) subcategory of memory, cognitive and compensation strategies reflects this, which are the members of the main category of direct strategies. What is more, indirect strategies, according to Dörnyei and Scott (1995), offer support for mutual understanding, such as making use of verbal markers or stimulating understanding to sustain the conversation. Similarly, Oxford (1990) attributes indirect strategies to those that support learning without the direct involvement of the target language. Interactional strategies place their primary emphasis on the cooperative conduction of problem-solving exchanges (e.g. providing clarification, requesting confirmation or asking for help). This is also comparable to Oxford's (1990) definition of social strategies.

The current study was based on Oxford's (1990) framework of language learning strategies and the specific strategic speaking behaviors framed by Dörnyei and Scott (1995). Indeed, Oxford's classification aimed at overall language learning but this study only focuses on speaking learning. Thus far, Dörnyei and Scott's (1995) taxonomy which is presumed to be more problem-oriented and process-based with specific strategic behaviors is also referred. Table 3 below presents the framework of speaking strategies used in this study.

Table 3. The Framework of Speaking Strategies Used in This Study

\begin{tabular}{lll}
\hline \multicolumn{1}{c}{ Categories } & \multicolumn{1}{c}{ Description } & \multicolumn{1}{c}{ Strategic speaking strategies } \\
\hline $\begin{array}{l}\text { Memory } \\
\text { strategies }\end{array}$ & $\begin{array}{l}\text { Structuring the process } \\
\text { of reviewing; building } \\
\text { mental links; retrieving. }\end{array}$ & $\begin{array}{l}\text { Putting a new word in a meaningful context for memory \& use } \\
\text { Revising previously learned knowledge in English } \\
\text { Thinking about new words before speaking } \\
\text { Imagining situation that speakers want to talk about }\end{array}$ \\
\hline $\begin{array}{lll}\text { Cognitive } \\
\text { strategies }\end{array}$ & $\begin{array}{l}\text { Enhancing learning } \\
\text { through various ways. }\end{array}$ & $\begin{array}{l}\text { Practicing listening and pronunciation through formal exercise } \\
\text { Structuring some ideas in mind before speaking } \\
\text { Using the dictionary to prepare vocabulary for speaking activity }\end{array}$ \\
\hline Compensation & Overcoming limitations; & $\begin{array}{l}\text { Making prediction from contextual and linguistic clues } \\
\text { strategies }\end{array}$ \\
& guessing based on clues & $\begin{array}{l}\text { Switching to mother tongue } \\
\text { Using mime and gestures }\end{array}$ \\
& & Using a synonym \\
\hline $\begin{array}{l}\text { Metacognitive } \\
\text { strategies }\end{array}$ & $\begin{array}{l}\text { Managing learning by } \\
\text { planning, organizing, }\end{array}$ & $\begin{array}{l}\text { Setting a goal or objective for a communicative task } \\
\text { Paying attention while speaking }\end{array}$ \\
& evaluating, monitoring & Evaluating learning outcomes \\
\hline
\end{tabular}




\begin{tabular}{lll}
\hline $\begin{array}{l}\text { Affective } \\
\text { strategies }\end{array}$ & $\begin{array}{l}\text { Reducing anxiety; } \\
\text { making positive } \\
\text { statement; viewing risk }\end{array}$ & $\begin{array}{l}\text { Taking deep breath or using laughter } \\
\text { Encouraging oneself } \\
\text { Exchanging feelings to other speakers }\end{array}$ \\
\hline $\begin{array}{l}\text { Social } \\
\text { strategies }\end{array}$ & $\begin{array}{l}\text { Asking others for help; } \\
\text { cooperating with others; } \\
\text { enhancing mutual }\end{array}$ & $\begin{array}{l}\text { Asking someone for mistake correction } \\
\text { Asking for clarification }\end{array}$ \\
& Practicing English with peers or proficient users \\
& Becoming aware of others' thoughts and feelings \\
\hline
\end{tabular}

\subsection{Previous studies}

Lopéz (2011)'s study sought to find what speaking strategies were used the most by the students from five public Mexican universities, which used a self-designed questionnaire with 14 speaking strategies. The results revealed that three speaking strategies most used by the students in their language learning including one compensation strategy (the use of paraphrasing or a synonym for unknown words) in the direct strategies and two social strategies (asking for repetition and asking for clarification) in the indirect strategies. His study also emphasized the importance of strategy training and encouraged teachers to apply and impart speaking strategies in communication classes beforehand. It is implied that the more strategies students use, the more success they gain in their speaking learning.

To explore the use of students' learning strategies in developing their speaking ability, Gani, Fajrina and Hanifa (2015) conducted a study on 16 participants being low and high speaking performance students at a high school in Indonesia. The data were garnered via 53-item questionnaires and interviews. The results recognized that high performance speaking students had better balance in using all kinds of learning strategies developed by Oxford (1990) for reinforcing their speaking skills. The low speaking performance students only focused on two learning strategies: compensation from the direct strategies and social from the indirect strategies. On the contrary, the high performance students employed more learning strategies appropriately compared to the low performance students.
Eskandari, Behjat and Kargar (2015) investigated the use of speaking strategies by 60 Iranian EFL university students, comprising of 35 female and 25 male students. An Oxford Proficiency Test was conducted to identify the students' proficiency level, assigned to three groups of high, intermediate, and low proficiency levels. Then, a 38-item strategy questionnaire was sent to these students. The result proved that gender and proficiency level played considerable roles in using metacognitive strategies, with females showing greater favor over this factor than males. Besides, high proficient students tended to be more interested than intermediate and low level ones. For compensation strategies, gender showed to have a significant influence on strategic choice, with males having more preference for this strategy group than females. For other groups like cognitive, memory, and socio-affective strategies, no statistically significant differences were found among variables of the study.

Bouaassria (2016)'s study probed speaking strategies used by Moroccan EFL university students. The study addressed the strategies the students used in developing speaking proficiency, as well as gender and motivation; and the most and least frequent strategies used. The study employed a quantitative method approach, using a questionnaire for data collection from 42 students. The results demonstrated that the students used a wide range of strategies that spread over six strategy groups, favoring memory and metacognitive strategies. Regarding strategy use related to learner factors, the results revealed a statistically significant relationship between the degree of liking English and students' 
overall strategy use. The results showed that speaking proficiency and gender significantly affected the use of strategies. Finally, the results also pointed out that the students had a low use of affective strategies.

\subsection{Research gaps}

Regarding the area of speaking learning strategies used among EFL learners, the previous studies above were conducted constantly (e.g. 2011, 2013, 2015, 2016) in foreign countries such as Mexico, Indonesia, Iran, or Marocco. Nonetheless, there has been no study at COFER, Ho Chi Minh City, Vietnam so far. It is inferred that the use frequency rate of speaking learning strategies also needs to be investigated and depicted in different contexts. Given these reasons, the current study investigated the reality of the English-majored sophomores' use of speaking learning strategies at this research site.

Pertinent to methodology, most of the previous studies above-mentioned primarily utilized questionnaires to get answers. Thus, the current study employed both quantitative results from the questionnaire and qualitative results from the semi-structured interview to assure triangulation of data collection methods.

\section{Methodology}

\subsection{Research setting and participants}

The study was conducted at Faculty of Business English of College of Foreign Economic Relations (COFER), Vietnam. COFER is an educational institution training students and providing them with college degrees and vocational certificates, doing research and making scientific and technological experiments in order to meet the requirements of training, production, business and services in commerce and society. Thanks to the convenience sampling technique, the researchers recruited the participation of
82 English-majored sophomores from two classes of TATM19I and TATM19K. Among these 82 EFL college students, there were 31 males, accounting for $37.8 \%$, and 51 females, constituting $62.2 \%$. Their English proficiency was expected to reach B1 level in the Common European Framework of Reference (CEFR).

\subsection{Research Design}

To garner sufficient data for the research questions, the current study utilized mixedmethods design, which is a procedure for mixing both quantitative and qualitative methods in a single study to address a research problem (Creswell \& Clark, 2011), "to provide a better understanding of the research problems and questions than either method by itself" (Creswell, 2012, p. 535). It is plain that each method needs to be saluted and their integrated use must contribute to healthy tensions and new insights (Creswell \& Clark, 2011). To this study, the researchers gathered quantitative data from the questionnaire $(\mathrm{N}=82)$ and then the interview results $(n=5)$ as qualitative data were used to support these quantitative results.

\subsection{Research instruments}

\section{Questionnaire}

The researchers decided to utilize a questionnaire which is known to be one of the easiest methods to manage, even with large numbers of subjects (Dörnyei, 2010), which helps researchers save time processing the results and gives them a clearer prediction from respondents' choice (Dörnyei, 2007). The 21-item questionnaire involved six distinct groups of speaking learning strategies adapted from Oxford (1990), Dörnyei and Scott (1995), including memory strategies (Items 1-4), cognitive strategies (Items 5-8), compensation strategies (Items 9-12), metacognitive strategies (Items 13-15), affective strategies (Items 16-18), and social strategies (Items 19-21). The items were rated on a five-point Likert-scale, including $1=$ never, 2 =rarely, $3=$ sometimes, 4=usually, and 5=always (see Appendix A). The 
questionnaire was highly reliable as proven by its Cronbach's Alpha value of 0.824 greater than 0.700 (Pallant, 2005).

\section{Semi-structured Interview}

Interview is used to provide a credible account of the collected data already yielded by the questionnaire (Mackey \& Gass, 2005). The researchers employed this useful tool so as to grasp a broader picture of the sophomores' EFL speaking learning strategy use. The combination of the questionnaire and interview permits a degree of triangulation in the study (Richards \& Schmidt, 2002). In harmony with the questionnaire, the semistructured interview included six questions in total, which addressed the English-majored sophomores' use of memory, cognitive, compensation, metacognitive, affective and social strategies, respectively, in terms of types, frequency and reasons (see Appendix B). The difference between the questionnaire items and the interview questions is that the latter could provide responses to "Why" questions in place of the former.

\section{Collection and analysis procedures}

The questionnaire copies which had been translated into Vietnamese beforehand were delivered to 82 participants. On the receipt of questionnaires from the respondents, the researchers found that all 80 copies $(100 \%)$ were valid and accepted. Finally, the researchers employed Statistical Package for the Social Sciences (SPSS) version 22.0 to analyze the descriptive statistics of the collected questionnaires in terms of percentage (P, \%), mean (M) and standard deviation (S.D.). Finally, the researchers organized the coded data into the pre-determined themes, including the participants' use of memory, cognitive, compensation, metacognitive, affective and social strategies, respectively.

After finishing the questionnaire treatment, the researchers invited five members from the target sample to participate in the interviews, and they were randomly chosen. They were labeled from S1 to S5. The interviews were conducted in the Vietnamese language using a set of semi-structured questions to ask and a tape recorder to record the interviewees' answers. Afterwards, the researchers transcribed and translated the interview transcripts for analysis. The qualitative data were arranged according to the questionnaire themes.

\section{Findings and Discussion}

Quantitative and qualitative analyses of the collected data were used to respond to the research question. With regard to quantitative analysis, the descriptive statistics in the forms of Mean (M) and Standard Deviation (S.D.) and Percentage $(\mathrm{P}, \%)$ from the questionnaire were run and presented in the following tables. Alternatively, qualitative data from the semi-structured interviews were analyzed and reported adjacently to the questionnaire results to provide further information or explain these data.

Table 4. The Sophomores' Use of Memory Strategies

\begin{tabular}{|c|c|c|c|c|c|c|c|c|c|}
\hline Item & Memory Strategies & & $\mathbf{N}^{*}$ & $\mathbf{R}^{*}$ & $S^{*}$ & $\mathbf{U}^{*}$ & $A^{*}$ & $\mathbf{M}$ & S.D. \\
\hline 1 & $\begin{array}{l}\text { I think about what is most important } \\
\text { to listeners so I can focus on it. }\end{array}$ & $\mathrm{P}(\%)$ & 0.0 & 2.4 & 26.8 & 47.6 & 23.2 & 3.91 & 0.773 \\
\hline 2 & $\begin{array}{l}\text { I visualize what I want to talk about to } \\
\text { help my speaking. }\end{array}$ & $\mathrm{P}(\%)$ & 1.2 & 11.0 & 32.9 & 34.1 & 20.7 & 3.62 & 0.977 \\
\hline 3 & $\begin{array}{l}\text { I learn new words by grouping them } \\
\text { by their meanings with contexts }\end{array}$ & $\mathrm{P}(\%)$ & 6.1 & 17.1 & 32.9 & 29.3 & 14.6 & 3.29 & 1.105 \\
\hline 4 & $\begin{array}{l}\text { I link my background knowledge to } \\
\text { what I am going to say. }\end{array}$ & $\mathrm{P}(\%)$ & 9.8 & 19.5 & 40.2 & 22.0 & 8.5 & 3.00 & 1.077 \\
\hline
\end{tabular}

(*) N: Never, R: Rarely, S: Sometimes, U: Usually, A: Always 
As Table 4 illustrates, nearly three quarters of the total sample reported that they frequently thought about important pieces of information to the listeners so that they could focus on those in their oral productions (Item 1, M=3.91, S.D. $=0.773,47.6 \%$ usually, $23.2 \%$ always). Likewise, it is apparent that many respondents also often visualized whatever they were going to speak (Item 2, $\mathrm{M}=3.62$, S.D. $=0.977,34.1 \%$ usually, $20.7 \%$ always). With respect to vocabulary learning which builds up linguistic competence for the students' speaking performance, only some English-majored sophomores learnt new words by grouping them by their meanings with different situational contexts (Item 3, $\mathrm{M}=3.29$, S.D. $=1.105,29.3 \%$ usually, $14.6 \%$ always). Contrary to three memory strategies above, it seems obvious that most of the students were not in favor of activating their background knowledge for speaking activities. Indeed, of all 82 surveyed sophomores, 16 students "rarely" (19.5\%) and 33 students "sometimes" (40.2\%) exploited this type (Item 4, M=3.00, S.D.=1.077).

Consonantly, the interview data also exhibit this preference on memory strategies perceived by the interviewees. Four of the five interviewees except for S3 stated that they frequently used memory strategies for their speaking learning. For example, S1, S2 and $\mathrm{S} 4$ revealed that they usually imagined or thought about some important ideas before speaking since it could help speakers focus on the main content of the utterances (S1), facilitate their thoughts during speaking (S2), or avoid hesitating to seek ideas during speaking (S4). S5 supplemented two types of memory strategies: she usually utilized her own background knowledge to expand her oral production during speaking activities, and used memory strategy in learning vocabulary for speaking tasks such as by grouping them in accordance with word family or word meaning. In contrast, S3 admitted that he did not frequently think about key information prior to his speaking; at the same time, he disregarded activating background knowledge for his oral production due to his dearth of this knowledge source.

Memory strategies enable the transfer of information to long-term memory and recall it for communication (Bölükbaş, 2013). Strikingly, both the quantitative and qualitative results of the study indicate that the majority of the participants preferably used memory strategies in their English speaking learning. Especially, they frequently imagined or thought about important pieces of information to the listeners so they could focus in their oral productions. The preference for this memory strategy was documented by the qualitative results that it could help speakers focus on the main content of the utterances, facilitate their thoughts during speaking, or avoid hesitating to seek ideas during speaking. It entails that memory strategies play a pivotal role in helping the speakers remember ideas of coming speech. However, only some Englishmajored sophomores at COFER learnt new words by grouping them in association with their meanings and putting them in different situational contexts. It is implied that to expand vocabulary memory capacity and to recall the words with ease, the learners should learn and practice them in varied contexts. In another point, both the results emerged from the questionnaire and interview highlight that most of the students ignored to activate their background knowledge for speaking activities. However, coupled with linguistic knowledge, topical knowledge has a great impact on learners' speaking performance (Bachman \& Palmer, 1996). Thus, it is imperative for speakers to exploit both language and background knowledge when orally producing English utterances. It should be noted that language knowledge is deemed as a means of communication (how to say) while topical knowledge looks like messages (what to say). 
Table 5. The Sophomores' Use of Cognitive Strategies

\begin{tabular}{|c|c|c|c|c|c|c|c|c|c|}
\hline Item & Cognitive Strategies & & $\mathbf{N}^{*}$ & $\mathbf{R}^{*}$ & $S^{*}$ & $\mathbf{U}^{*}$ & $\mathbf{A}^{*}$ & $\mathbf{M}$ & S.D. \\
\hline 5 & $\begin{array}{l}\text { I structure or take notes of some ideas } \\
\text { before speaking. }\end{array}$ & $\mathrm{P}(\%)$ & 4.9 & 8.5 & 32.9 & 43.9 & 9.8 & 3.50 & 0.958 \\
\hline 6 & $\begin{array}{l}\text { I use the dictionary to prepare some } \\
\text { vocabulary for my speaking activity. }\end{array}$ & $\mathrm{P}(\%)$ & 8.5 & 6.1 & 28.0 & 29.3 & 28.0 & 3.62 & 1.203 \\
\hline 7 & $\begin{array}{l}\text { Imyself practice some formal exercises } \\
\text { to improve my pronunciation, } \\
\text { listening ability, relating to speaking } \\
\text { ability. }\end{array}$ & $\mathrm{P}(\%)$ & 12.2 & 23.2 & 29.3 & 31.7 & 3.7 & 2.91 & 1.091 \\
\hline 8 & $\begin{array}{l}\text { I repeat silently to myself when } \\
\text { someone is speaking English. }\end{array}$ & $\mathrm{P}(\%)$ & 2.4 & 7.3 & 23.2 & 41.5 & 25.6 & 3.80 & 0.897 \\
\hline
\end{tabular}

(*) N: Never, R: Rarely, S: Sometimes, U: Usually, A: Always

As can be seen from Table 5, one-third of the total sample only "sometimes" structured or took notes of some ideas before their speaking (32.9\%); yet, up to $43.9 \%$ of the total participants "usually" practiced this strategy (Item 5, M=3.50, S.D.=0.958). Besides, for Item 6 , many students also frequently used the dictionary to prepare some needed vocabulary for their speaking activities ( $\mathrm{M}=3.62$, S.D. $=1.203$, 29.3\% usually, 28.0\% always). However, it is observable that in speaking learning, formal exercises of pronunciation and listening skills were not favorably experienced by the surveyed students (Item 7, $\mathrm{M}=2.91$, S.D. $=1.091,23.2 \%$ rarely, $29.3 \%$ sometimes). In contrast, approximately twothirds of the response community highly appreciated the repetition strategy (Item 8, $\mathrm{M}=3.80$, S.D. $=0.897,41.5 \%$ usually, $25.6 \%$ always). Specifically, within this cognitive strategy, these students repeated to themselves when someone was speaking English.

The qualitative data, congruously, verified the actual utilization of this strategy category. All the five interviewees claimed that they frequently employed cognitive strategies when learning speaking lessons. According to these students, cognitive strategies could help them manipulate language input to produce output, and monitor their speaking process. In particular, four of the five participants mentioned using dictionary to look up meaning (S1, S3), to check pronunciation (S3), or to prepare some necessary words for their speaking tasks (S2, S3, and S4). In addition, S2 and S5 unraveled that they frequently made a list of some key ideas before speaking. Furthermore, three out of the five interviewed students stated that they often repeated silently to themselves when someone was speaking (S3, S4, and S5). However, only S5 was often concerned about listening comprehension and pronunciation exercises. She considered that these language elements were closely associated with the good quality of speaking performance.

With reference to cognitive strategies, the quantitative findings cleared up that this strategy group was much practically regarded by many English-majored sophomores of COFER. Indeed, many often structured or made a list of some key ideas before speaking as well as used the dictionary to prepare some needed vocabulary for their speaking activities. Consistently, the qualitative results from the interview produced the similar trend. These cognitive strategies are actually beneficial to speakers since they help them to manage the content of coming speech, and to facilitate spontaneous vocabulary recalling while speaking. However, only a much smaller group of the students practiced formal exercises of pronunciation and listening skills, which can enrich their language input necessary for their oral productions. Leong and Ahmadi (2017) proved that learners are unable to develop their speaking competence 
until they improve their listening ability. Indeed, any communicators have the dual role of listeners and speakers, in which they have to listen to what is uttered by others and then reply accordingly. Most strikingly, almost all the sophomores frequently repeated silently to themselves when their partners were making their speech. Actually, this action is deemed as a valuable tool in keeping track of what the other speakers are uttering and then the learners can catalyze their responses immediately. In sum, these cognitive strategies (e.g. structuring ideas and preparing language input before speaking, repetition, or listening and pronunciation practice) are necessarily important for speakers. These strategies help learner speakers to develop the thinking skills that make them strategic and flexible (Ellis, 1997), which improve speakers' knowledge and their understanding of linguistic system.

Table 6. The sophomores' use of compensation strategies

\begin{tabular}{|c|c|c|c|c|c|c|c|c|c|}
\hline Item & Compensation Strategies & & $\mathbf{N}^{*}$ & $\mathbf{R}^{*}$ & $S^{*}$ & $\mathbf{U}^{*}$ & $A^{*}$ & $\mathbf{M}$ & S.D. \\
\hline 9 & $\begin{array}{l}\text { When I cannot think of a word, I use } \\
\text { Vietnamese. }\end{array}$ & $\mathrm{P}(\%)$ & 0.0 & 0.0 & 20.7 & 34.1 & 45.1 & 4.24 & 0.779 \\
\hline 10 & $\begin{array}{l}\text { When I cannot recollect a word, I use } \\
\text { known words/ phrases (i.e. synonyms). }\end{array}$ & $\mathrm{P}(\%)$ & 6.1 & 8.5 & 24.4 & 6.1 & 54.9 & 3.95 & 1.304 \\
\hline 11 & $\begin{array}{l}\text { When I cannot think of a word, I use } \\
\text { gestures. }\end{array}$ & $\mathrm{P}(\%)$ & 0.0 & 17.1 & 25.6 & 36.6 & 20.7 & 3.61 & 1.003 \\
\hline 12 & $\begin{array}{l}\text { I use either contextual or linguistic } \\
\text { clues to understand what is being } \\
\text { uttered by others. }\end{array}$ & $\mathrm{P}(\%)$ & 0.0 & 20.7 & 26.8 & 31.7 & 20.7 & 3.52 & 1.045 \\
\hline
\end{tabular}

(*) N: Never, R: Rarely, S: Sometimes, U: Usually, A: Always

As indicated in Table 6, most of the participants favored code-switching with the highest level (Item 9, M=4.24, S.D. $=0.779$, $45.1 \%$ usually, $34.1 \%$ always). Specifically, when unable to think of a word during a conversationinEnglish, theyusedaVietnamese equivalent. Similarly, a large number of the participants reported that when not knowing how to say something, they often employed synonyms to compensate for communication breakdown (Item 10, M=3.95, S.D.=1.304, $54.9 \%$ always). In many cases, gestures or any non-verbal forms also turned out to be the useful tool for many learner speakers to overcome the uncomfortable situation when they were incapable of seeking a word during a conversation in English (Item 11, $\mathrm{M}=3.61$, S.D. $=1.003$, 36.6\% usually, $20.7 \%$ always). Furthermore, for Item $12(\mathrm{M}=3.52$, S.D.=1.045), during communication, roughly half of the total sample often employed either contextual or linguistic clues to understand what was being uttered by others $(31.7 \%$ usually, $20.7 \%$ always). In general, a great part of the students seemed to prefer compensation strategies in their speaking learning.

Qualitatively, the interview results also yielded the same trend. All the five interviewees determined that they frequently used compensation strategies to minimize their communication breakdown. To be specific, three out of the five students including S2, S4 and S5 revealed that they often utilized synonyms, antonyms or circumlocution to express what they intended, especially when they could not recall those words exactly. Therewith, S2 and S5 shared the same practice in employing non-verbal communication forms such as mimes, gestures, and facial expressions to rescue them and overcome linguistic or topical limitations and gain their self-confidence if any. Furthermore, S4 and S5 also frequently focused on contextual or linguistic clues (e.g. intonation, stress, linking words) to understand the meaning of others' speech. Both of them pointed out that this strategy was really helpful to get the general messages from a string of utterances involving 
too many unfamiliar words or phrases. Additionally, both S1 and S5 supplemented that they also often switched to their mother tongue (Vietnamese) when they could not recall needed vocabulary. More specifically, S1 admitted that her English lexicon is too small.

Compensation strategies have come to the rescue to help the learners to overcome their problems in their speaking learning (Bölükbaş, 2013). This author exemplifies some strategies belonging to this group such as making logical guesses, overcoming language limitations while speaking, and using body language. Both the quantitative and qualitative results highlighted that most of the students favorably employed different sets of compensation strategies in case that they confronted some linguistic or topical constraints. To begin with, they often switched to their mother tongue or borrowed synonyms or circumlocution when they were unable to recall a word during a conversation in English. Besides, mimes, gestures or any other non-verbal forms also became the useful tool for many learner speakers to overcome their lack of vocabulary. Interestingly, a great part of the participants also usually made their guesses based on linguistic or contextual clues to minimize their unpleasant communication breakdown. Through qualitative results, it is inferred that this strategy was really helpful to get the general messages from a string of utterances involving too many unfamiliar words or phrases. Finally, a notable finding was ultimately found in the interview that selecting familiar topics for speaking practice was also a good idea to improve speaking performance, especially among low proficient speakers. It is clear that in speaking learning, students will meet several difficulties negatively affecting their speaking performance like their paucity of linguistic resources, scarcity of topical knowledge, or deficiency in listening comprehension. To rescue themselves from these common problems, the students need to exploit compensation strategies effectively (Hendriani, 2013).

Table 7. The Sophomores' Use of Metacognitive Strategies

\begin{tabular}{|c|c|c|c|c|c|c|c|c|c|}
\hline Item & Metacognitive Strategies & & $\mathbf{N}^{*}$ & $\mathbf{R}^{*}$ & $S^{*}$ & $\mathbf{U}^{*}$ & $\mathbf{A}^{*}$ & $\mathbf{M}$ & S.D. \\
\hline 13 & $\begin{array}{l}\text { Before speaking, I set up a clear goal } \\
\text { to push up my motivation. }\end{array}$ & $\mathrm{P}(\%)$ & 0.0 & 4.9 & 31.7 & 35.4 & 28.0 & 3.87 & 0.886 \\
\hline 14 & $\begin{array}{l}\text { While speaking, I pay attention when } \\
\text { someone is speaking English. }\end{array}$ & $\mathrm{P}(\%)$ & 0.0 & 0.0 & 28.0 & 39.0 & 32.9 & 4.05 & 0.784 \\
\hline 15 & $\begin{array}{l}\text { After speaking, I evaluate how well } \\
\text { the task has been done. }\end{array}$ & $\mathrm{P}(\%)$ & 14.6 & 30.5 & 36.6 & 18.3 & 0.0 & 2.59 & 0.955 \\
\hline
\end{tabular}

(*) N: Never, R: Rarely, S: Sometimes, U: Usually, A: Always

From the data analysis in Table 7, it is apparent that all the 82 participants paid their attention to what was spoken by their interlocutors at any rate (Item $14, \mathrm{M}=4.05$, S.D. $=0.784)$. Specifically, $28.0 \%, \quad 39.0 \%$ and $32.9 \%$ of the total sample "sometimes", "usually", and "always" practiced this metacognitive strategy while speaking. Likewise, to push up their motivation for speaking, almost all the participants set up a clear goal before their oral productions regardless of frequency (Item 13, M=3.87,
S.D. $=0.886, \quad 31.7 \% \quad$ sometimes,$\quad 35.4 \%$ usually, $28.0 \%$ always). Unlike the two metacognitive strategies mentioned above, it can be observed from Item 15 that the majority of the respondents were ignorant of evaluating strategy after their speaking $(\mathrm{M}=2.59$, S.D. $=0.955,14.6 \%$ never, 30.5\% rarely, $36.6 \%$ sometimes).

Consistently, the qualitative data obtained from the interviews also demonstrated the similar fashion. All the five interviewed students espoused that they frequently used 
metacognitive strategies at before-speaking phase like cognitively setting up their clear goals for speaking tasks, increasing their motivation to complete these communicative tasks. Furthermore, S2, S4 and S5 also frequently planned some ideas and language input like words, phrases and grammatical structures for their coming speech production. Based on their explanation, these strategies could direct them to speak out what should be necessary and even rescue them from communication breakdown. Similarly, while speaking, all the five interviewees favorably exploited metacognitive strategies. In reality, all of them paid much attention to whatever someone was speaking. In accordance to these interviewees, this indirect strategy facilitated them to understand thesentmessages most fully. However, it seemed that some interviewees were ignorant of employing metacognitive strategies after their speaking including S1, $\mathrm{S} 3$, and S4. To clarify this indifference, some causal factors were ultimately found. S1 stated that she did not have much time for the post-speaking phase, and she personally assumed that strategies used after speaking were not more necessarily important than those in before- and while-speaking phases.
Likewise, S3 was not consciously aware of the necessity of metacognitive strategies applied after his speaking. S4 admitted that she was actually unconcerned about using metacognitive strategies after her speaking like self-evaluating. Nevertheless, S2 and S5 reckoned that metacognitive strategies should be applied after their speaking so that they can erase their weaknesses and reinforce their strong points in their English oral productions.

Theoretically, Gani, Fajrina and Hanifa (2015) acknowledge that the necessity of metacognitive strategies that they can help learners to regulate their own cognitive abilities and to plan, monitor and evaluate their speaking progress as they move toward communicative competence. Similarly, these metacognitive strategies can facilitate students' speaking activities through planning and monitoring, and improve their speaking performance not only this time but also other times via self-evaluating (Oxford, 1990). Thus, the students in this study need to use self-evaluation more frequently to see where their mistakes and flaws are in terms of fluency, accuracy or appropriacy, and then they can avoid them and make better subsequent speaking performance.

Table 8 . The sophomores' use of affective strategies

\begin{tabular}{|c|c|c|c|c|c|c|c|c|}
\hline Item & Affective Strategies & $\mathbf{N}^{*}$ & $\mathbf{R}^{*}$ & $S^{*}$ & $\mathbf{U}^{*}$ & $A^{*}$ & M & S.D. \\
\hline 16 & $\begin{array}{l}\text { I try to relax or breathe deeply to } \mathrm{P}(\%) \\
\text { reduce anxiety before speaking. }\end{array}$ & 0.0 & 0.0 & 29.3 & 41.5 & 29.3 & 4.00 & 0.700 \\
\hline 17 & $\begin{array}{l}\text { Before speaking, I encourage myself } \mathrm{P}(\%) \\
\text { that I can finish the speaking task. }\end{array}$ & 0.0 & 8.5 & 32.9 & 37.8 & 20.7 & 3.71 & 0.896 \\
\hline 18 & $\begin{array}{l}\text { I share my feeling with my friends to } \mathrm{P}(\%) \\
\text { increase my self-confidence. }\end{array}$ & 7.3 & 17.1 & 30.5 & 26.8 & 18.3 & 3.32 & 1.175 \\
\hline
\end{tabular}

(*) N: Never, R: Rarely, S: Sometimes, U: Usually, A: Always

As shown in Table 8, nearly three quarters of the questionnaire respondents reported that they relaxed and breathed deeply to reduce their anxiety before producing English orally (Item 16, M=4.00, S.D. $=0.770,41.5 \%$ usually, $29.3 \%$ always). In a similar vein, many English-majored sophomores also frequently encouraged themselves that they could accomplish the speaking task well (Item 17, $\mathrm{M}=3.71$, S.D. $=0.896$, 37.8\% usually, $20.7 \%$ always). Nevertheless, it is apparent that not many students preferred the other affective strategy that they needed to share their feeling with their friends to increase their selfconfidence when speaking (Item 18, $\mathrm{M}=3.32$, S.D. $=1.175,17.1 \%$ rarely, $30.5 \%$ sometimes). 
This tendency, concomitantly, was found in the interviews. Three out of the five interviewees frequently confronted affective problems (S1, S3, and S4), while S2 and S5 only occasionally experienced these problem types in a few cases. Specifically, S1 was almost always nervous or embarrassed when presenting ideas or performing speaking tasks in front of the class. To overcome this negative psychological state, she used "deeply breathing" technique. In case of $\mathrm{S} 3$, he often felt uncomfortable and shy when being asked to make speech; therefore, apart from breathing deeply before orally producing words, he used his body language to make himself more comfortable. Likewise, S4 usually showed her low self-efficacy in oral productions. With her expectation of relieving this negative factor, she also usually breathed deeply and encouraged herself that she could complete the speaking tasks successfully. Meanwhile, S2 sometimes became anxious when speaking English and he considered that deeply breathing, smiling and even practicing speech in front of a mirror could help him to get rid of anxiety and then his speaking performance got better. Specific to S5's circumstance, she only seldom turned out to be unconfident a little bit when she met a strange speaking topic and her background knowledge was unsatisfactorily adequate. Henceforth, she had to encourage herself to finish the speaking tasks as well as possible.
In language learning, affective strategies should be deployed since these strategies help speakers "develop self-confidence" (Gani, et al., 2015, p. 21), and "control their feelings, motivation and attitudes related with learning" (Bölükbaş, 2013, p. 57). Emphatically, most of the questionnaire respondents often tried to relax and breathed deeply to reduce their anxiety before producing English orally. At the same time, they encouraged themselves that they could accomplish the speaking tasks successfully. It means that these students highly approved of utilizing affective strategies to manage their negative feelings and psychological states. In addition to these strategies, the qualitative results showed that smile, body language movements and even self-talk with a mirror also enabled speakers to get rid of anxiety and raise their self-confidence. Obviously, successful oral productions of EFL learners also can be impeded by their affective states such as motivation, selfconfidence, and anxiety (Oxford, 1990). In fact, Leong and Ahmadi (2017) testified that learners with low self-esteem, higher anxiety, and low motivation have serious difficulties in building up speaking ability. Therefore, students should maximize their use of affective strategies like "reducing anxiety, encouraging oneself" (Bölükbaş, 2013, p. 57) in their speaking learning.

Table 9. The Sophomores' Use of Social Strategies

\begin{tabular}{|c|c|c|c|c|c|c|c|c|c|}
\hline Item & Social Strategies & & $\mathbf{N *}$ & $\mathbf{R}^{*}$ & $S^{*}$ & $\mathbf{U}^{*}$ & $A^{*}$ & $\mathbf{M}$ & S.D. \\
\hline 19 & $\begin{array}{l}\text { I ask my partners to repeat a word/ } \\
\text { phrase if I do not hear it clearly. }\end{array}$ & $\mathrm{P}(\%)$ & 0.0 & 4.9 & 20.7 & 32.9 & 41.5 & 4.11 & 0.903 \\
\hline 20 & $\begin{array}{l}\text { If I do not know how to say something, } \\
\text { I ask a more proficient speaker for } \\
\text { help. }\end{array}$ & $\mathrm{P}(\%)$ & 9.8 & 13.4 & 32.9 & 17.1 & 26.8 & 3.38 & 1.283 \\
\hline 21 & $\begin{array}{l}\text { While speaking, I am aware of others' } \\
\text { thoughts to modify my utterances. }\end{array}$ & $\mathrm{P}(\%)$ & 0.0 & 22.0 & 23.2 & 35.4 & 19.5 & 3.52 & 1.045 \\
\hline
\end{tabular}

(*) N: Never, R: Rarely, S: Sometimes, U: Usually, A: Always

Table 9 depicts that a big proportion of the participants frequently exploited the first type of social strategies (Item 19, M=4.11,
S.D. $=0.903,32.9 \%$ usually, $41.5 \%$ always); they asked their partner to repeat a word or phrases if they did not hear it clearly. The 
second type of social strategies, namely asking a more proficient speaker for help, was also favored by some students (Item 20, $\mathrm{M}=3.38$, S.D. $=1.238,17.1 \%$ usually, $26.8 \%$ always). Interestingly, more than half of the participants frequently took the partners' thoughts and feelings into account to modify their utterances suitably (Item 21, M=3.52, S.D. $=1.045,35.4 \%$ usually, $19.5 \%$ always).

Qualitatively, all the five interviewees highly applauded that social strategies significantly enhanced their speaking performance, and in reality, they used social strategy group at high frequency rate. In particular, these participants almost always asked their partners to clarify their unclear speech (S2, S3), to paraphrase their ideas (S1, S5) or to alter difficult words (S4) during oral productions. Additionally, S1 and S4 uncovered that they also often asked help from their more-proficient classmates in suggesting ideas or vocabulary or language forms. In discrete case of S2, he usually tended to seek his partners for speaking practice and consequently he could improve his speaking ability, especially in terms of fluency. Interestingly, in the process of exchanging ideas, S5 usually took her partners' current ability and thoughts into account so that she could modify her speech suitably.

As far as social strategies are concerned, it is believed that social strategies can maintain mutual understanding among speakers (Oxford, 1990). In this study, a large number of the respondents preferably employed these social strategies for their better speaking performance. In general, social strategies can provide increased interaction and more empathetic understanding for speakers. Past research (e.g. Gani, Fajrina \& Hanifa, 2015; Than, 2019; Truong, 2019) has documented that learning from different resources like from teachers, friends, classmates, can maximize the learners' learning outcomes. Thus, social strategies need to be more frequently practiced in EFL speaking classrooms.

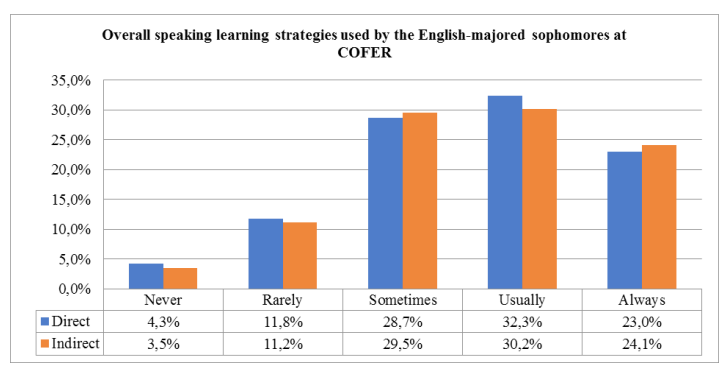

Chart 1. Overall Speaking Learning Strategies Used by the English-majored Sophomores at COFER

As can be seen from Chart 1, both direct and indirect strategy classes were quite equally employed in their speaking learning. To highlight this conclusion, each of the frequency rates from both classes was compared in pair; for example, "never" rate $(4.3 \%$ and $3.5 \%)$, "rarely" $(11.8 \%$ and $11.2 \%)$, "sometimes" rate (28.7\% and $29.5 \%)$, "usually" (32.3\% and 30.2\%), and "always" rate $(23.0 \%$ and $24.1 \%)$, respectively. Overall, a majority of the participants, in their EFL oral acquisition, employed a diversity of speaking learning strategies to facilitate their speaking learning process and enhance their speaking performance in terms of fluency, accuracy and appropriacy. As an illustration of this, 32.3\% and $23.0 \%$ of the participants "usually" and "always" exploited the direct strategy class, respectively such as memory strategies, cognitive strategies and compensation strategies. Meanwhile, $30.2 \%$ and $24.1 \%$ "usually" and "always" exploited the indirect class including metacognitive strategies, or affective-social strategies, respectively.

According to Oxford (1990), all six types of learning strategies, no matter whether they are direct or indirect, interact with each other. It means that in speaking learning, students need to use these strategies flexibly and skillfully but separately. To this survey, the notable findings concluded that direct (e.g. memory, cognitive, compensation) and indirect (e.g. metacognitive, affective, social) strategy classes were quite equally employed in their speaking learning. To recap, the 
English-majored sophomores at COFER should use appropriate language learning strategies more consciously, purposefully, and frequently to be more successful in developing their speaking skills (Lopéz, 2011; Gani, et al., 2015). In fact, the students may encounter different speaking problems, and if they only possess a limited range of speaking strategies, they fail to sustain their simple communication. Since communication is a complicated process, summoning different components, students are required to utilize different strategies flexibly so that they can survive in any given communicative situation.

\section{Conclusion}

Although this study faced some limitations such as the time restriction for carrying out the study and the small number of participants, it also yielded remarkable findings as follows. Both direct (memory strategies, cognitive strategies and compensation strategies) and indirect strategy classes (metacognitive strategies, affective-social strategies) were practically favored in English speaking learning of the English-majored sophomores at COFER. Overall, it is a positive signal that the majority of the participants, in their EFL oral acquisition, usually employed a diversity of speaking learning strategies to facilitate their learning process, improve their speaking performance in terms of fluency, accuracy and appropriacy, and nourish their motivation and self-confidence in oral production. The most frequently used learning strategy in each strategy group consisted of (1) structuring or planning of ideas and language input, (2) using dictionary for vocabulary learning, (3) compensating for linguistic limitations by code-switching, non-verbal forms, synonyms, (4) paying attention, (5) deeply breathing, and (6) asking for clarification. However, activating prior knowledge, self-training language input, self-evaluating speaking performance were less frequently used among many students.

\section{Implications}

Firstly, both the quantitative and qualitative results implied that background knowledge was not prioritized by almost all the participants in their speaking learning. In fact, many students found it difficult to continue their oral production due to their lack of topic knowledge. It is recommended that they should take advantage of this knowledge source since it helps oral communication more interesting, persuasive and realistic. Specifically, students can exploit this knowledge source to compare, contrast, or illustrate what they are speaking. In sum of this point, teachers should make students aware of the importance of background knowledge and create more opportunities for students to utilize their prior knowledge in their speaking performance.

Secondly, all the questionnaire and interview yielded the overlapped results that many English-majored sophomores did not frequently practice their listening skills and pronunciation. On the other hand, they admitted that they were deficient of listening comprehension and sound vocalization. Teachers should encourage students to do so. Once again, listening ability and the ways of producing sounds directly impact the quality of speech.

Thirdly, after speaking, most of the students neglected self-evaluating what they had done previously. Based on this finding, the study suggests that teachers should guide students how to assess their own speaking performance. From that, they can minimize or even eliminate these weak points and fortify their good points.

Fourthly, the results emerged from both instruments indicated that some students were much anxious and unconfident when speaking English. Research has shown that such affective problems can negatively hinder thoughts and use of language and knowledge during their speaking activities. Thus, it is the teachers' role to facilitate a relaxing 
environment for students to be relaxed and motivated to gain pre-determined speaking goals.

\section{References}

Anderson, N. J. (2003). Metacognitive reading strategies increase L2 performance. The Language Teacher, 27, 20-22.

Bachman, L., \& Palmer, A. S. (1996). Language Testing in Practice. Oxford: Oxford University Press.

Bouaassria, F. (2016). The use of learning strategies in developing speaking skills among Moroccan university EFL learners: Moulay Ismail university as a case study (Unpublished bachelor's degree). Morocco: Mohammed V University.

Bölükbaş, F. (2013). The Effect of Language Learning Strategies on Learning Vocabulary in Teaching Turkish as a Foreign Language. H. U. Journal of Education, 28(3), 55-68.

Brown, G. \& Yule, G. (1983). Teaching Spoken Language. Cambridge: Cambridge University Press.

Brown, H. D. (2001). Teaching by Principles: An Interactive Approach to Language Pedagogy. White Plains, NY: Longman.

Cameron, D. (2001). Working with Spoken Discourse. Oxford: SAGE Publications, Ltd.

Carnegie, D. (1977). The Quick and Easy Way to Effective Speaking. New York: Association Press.

Chamot, A.U. (2004). Issues in Language Learning Strategy Research and Teaching. Electronic Journal of Foreign Language Teaching, 1(1),14-26.

Creswell, J. W., \& Clark, P. V. L. (2011). Designing and Conducting Mixed Methods Research (2nd ed.). Thousand Oaks, CA: Sage.

Creswell, J. W. (2012). Educational Research: Planning, Conducting, and Evaluating Quantitative (4th ed.). Boston, MA: Pearson Education.

Dörnyei, Z., \& Scott, M. L. (1995). Communication Strategies: An empirical analysis with retrospection. In J. S. Turley \& K. Lusby (Eds.), Selected papers from the proceedings of the 21st Annual Symposium of the Deseret Language and Linguistics Society (pp. 155168). Provo: Brigham Young University Press.

Dörnyei, Z. (2007). Research Methods in Applied Linguistics. Oxford, UK: Oxford University Press.

Dörnyei, Z. (2010). Questionnaires in Second Language Research: Construction, Administration, and Processing (2nd ed.). London, Routledge.

Ellis, R. (1997). The Study of Second Language Acquisition. Oxford: Oxford University Press.

Eskandari, P., Behjat, F., \& Kargar, A. S. (2015). An Investigation of Speaking Strategies Employed by
Iranian EFL Students. Journal of Academic and Applied Studies, 5(8), 23-55.

Gani, S. A., Fajrina, D., \& Hanifa, R. (2015). Students' Learning Strategies for Developing Speaking Ability. Studies in English Language and Education, 2(1), 16-28.

Hedge, T. (2000). Teaching and Learning in the Language Classroom. Cambridge: Cambridge University Press.

Hendriani, S. (2013). Developing a model of learning strategy of speaking English at college. International Review of Social Sciences and Humanities, 6(1), 104-112.

Hismonoglu, M. (2000). Language learning strategies in foreign language learning and teaching. The Internet TESL Journal, 6(8).

Kayi, H. (2006). Teaching speaking: Activities to promote speaking in a second language. The Internet TESL Journal, 12(11).

Lindsay, C., \& Knight, P. (2006). Learning and Teaching English: A Course for Teachers. Oxford: Oxford University Press.

Leong, L-M., \& Ahmadi, S. M. (2017). An Analysis of Factors Influencing Learners' English Speaking Skill. International Journal of Research in Language Education, 34-41.

Lopéz, M. M. (2011). Speaking strategies used by BA ELT students in public universities in Mexico. Mextesol Journal, 35(1), 1-22.

Mackey, A., \& Gass, S. M. (2005). Second Language Research: Methodology and Design. Mahwah, NJ: Lawrence Erlbaum.

Mahripah, S. (2014). Exploring Factors Affecting EFL Learners' Speaking Performance: from Theories into Practices. Proceedings of the 3rd UAD TEFL International Conference 2014 "Materials Development in Asia and Beyond: Directions, Issues, and Challenges". English Education Department, Universitas Ahmad Dahlan, Yogyakarta, Indonesia.

Nakatani, Y. (2005). The effects of awareness raising training on oral communication strategy use. The Modern Language Journal, 89(1), 76-91.

Nunan, D. (1991). Language Teaching Methodology. A Textbook for Teachers. New York: Prentice Hall International, Ltd.

O’Malley, J. M., \& Chamot, A. U. (1990). Learning Strategies in Second Language Acquisition. Cambridge University Press.

Oxford, R. L. (1990). Language Learning Strategies: What Every Teacher Should Know. New York: Newbury House.

Pallant, J. (2005). SPSS Survival Guide: A Step by Step Guide to Data Analysis Using SPSS for Windows (3rd ed.). New York: Open University Press.

Phan, N. D. A. (2014). A study of the application 
of Cooperative Language Learning in teaching English speaking skill at the University of Information Technology (Unpublished master's thesis). Vietnam: Ho Chi Minh City Open University.

Rababa'h, G. (2005). Communication problems facing Arab learners of English. Journal of Language and Learning, 3(1), 180-197.

Rachmawati, Y. (2012). Language Learning Strategies Used by Learners in Learning Speaking (A Descriptive Study in an Exemplary Class in One of Senior High Schools in Cimahi) (Unpublished master's thesis). Indonesia: Indonesia University of Education.

Richards, J. C. (2002). Methodology in Language Teaching. Cambridge: Cambridge University Press.

Richards, J. C. \& W. A. Renandya 2002). Methodology in Language Teaching: An Anthology of
Current Practice. Cambridge: Cambridge University Press.

Richards, J. C., \& Schmidt, R. (2002). Longman Dictionary of Language Teaching and Applied Linguistics. London, UK: Longman: Pearson Education.

Than, T. L. (2019). Speaking Problems and Causal Factors Perceived by the Eleventh Graders at Tay Ninh High School (Unpublished master's thesis). Vietnam: Ho Chi Minh City Open University.

Thornbury, S. (2005). How to Teach Speaking. London: Longman.

Truong, T. H. N. (2019). The use of drama in teaching EFL speaking to second year EFL learners at Ho Chi Minh City University of Science (Unpublished master's thesis). Vietnam: Ho Chi Minh City Open University.

Ur, P. (1996). A Course in Language Teaching. Cambridge: Cambridge University Press.

\title{
CHIẾN LƯợC HỌC KỸ NĂNG NÓI CỦA SINH VIÊN NĂM THỬ HAI TRƯỜNG CAO ĐẲNG KINH TẾ ĐỐI NGOẠI
}

\author{
Trương Minh Hòa ${ }^{1}$, Phan Thị Miên Thảo² \\ 1. Đại học Nguyễn Tất Thành, \\ $300 A$ - Nguyến Tất Thành, Phuờng 13, Quận 4, TP. Hồ Chí Minh, Việt Nam \\ 2. Trường Ngoại ngũ Đông Phwơng Mới, \\ 4/34 - Quang Trung, Xã Thới Tam Thôn, Huyện Hóc Môn, TP. Hồ Chí Minh, Việt Nam
}

Tóm tắt: Nhu cầu về kỹ năng giao tiếp tốt trong một xã hội toàn cầu hóa ngày càng tăng cao đã thúc đẩy việc học nói tiếng Anh trên khắp thế giới. Cụ thể hơn với bối cảnh Việt Nam, sau nhiều năm tiếp xúc với tiếng Anh, hầu hết sinh viên cao đẳng, đại học vẫn còn giao tiếp kém hiệu quả trong các tình huống thực tế do họ chưa có được những chiến lược học nói hiệu quả. Xét về mục đích, nghiên cứu này nhằm khám phá các chiến lược học nói của 82 sinh viên năm thứ hai chuyên ngành tiếng Anh tại Trường Cao đẳng Kinh tế Đối ngoại (COFER), Thành phố Hồ Chí Minh, Việt Nam. Thiết kế phương pháp hỗn hợp đã được sử dụng để thu thập dữ liệu, gồm hai công cụ nghiên cứu là bảng câu hỏi và phỏng vấn bán cấu trúc. Trong khi dũ liệu định lượng thu được từ bảng câu hỏi được phân tích bằng SPSS 22.0 thì kết quả phỏng vấn được phân tích theo chủ đề. Kết quả nghiên cứu chỉ ra rằng phần lớn các sinh viên năm thứ hai chuyên ngành tiếng Anh thường sử dụng cả chiến lược trực tiếp và gián tiếp. Các chiến lược được sử dụng thường xuyên nhất bao gồm cấu trúc hoặc lập kế hoạch cho ý tưởng và ngôn ngữ, sử dụng từ điển để học từ vựng, khỏa lấp cho những hạn chế về ngôn ngữ bằng cách chuyển đổi mã, diễn tả bằng hình thức phi ngôn ngữ, từ đồng nghĩa, tập trung chú ý, thở sâu và đề nghị người nói làm rõ ý. Tuy nhiên, việc sử dụng kiến thức nền, tự chuẩn bị ngôn ngữ, tự đánh giá hiệu suất nói không được nhiều sinh viên sử dụng.

Tù khóa: chiến lược học tập nói, chuyên ngành tiếng Anh, sinh viên năm hai, Cao đẳng Kinh tế Đối ngoại 


\section{APPENDIX A: QUESTIONNAIRE}

\begin{tabular}{|c|c|c|c|c|c|c|}
\hline $\begin{array}{l}\text { How } \\
\text { Pleas } \\
\text { 1=Ne }\end{array}$ & $\begin{array}{l}\text { often do you employ speaking learning strategies? } \\
\text { e put a cross }(X) \text { and rate yourself based on the given statements using the following scale: } \\
\text { ver } \quad \mathbf{2}=\text { Rarely } \quad \mathbf{3}=\text { Sometimes } \quad \mathbf{4}=\text { Usually } \quad \mathbf{5}=\text { Always }\end{array}$ & & & & & \\
\hline No. & Statement & & ale & & & \\
\hline Mem & ory Strategies & & & & & \\
\hline 1 & I think about what is most important to listeners so I can focus on it. & 1 & 2 & 3 & 4 & 5 \\
\hline 2 & I visualize what I want to talk about to help my speaking. & 1 & 2 & 3 & 4 & 5 \\
\hline 3 & I learn new words by grouping them by their meanings with contexts & 1 & 2 & 3 & 4 & 5 \\
\hline 4 & I link my background knowledge to what I am going to say. & 1 & 2 & 3 & 4 & 5 \\
\hline Cogn & itive Strategies & & & & & \\
\hline 5 & I structure or take notes of some ideas before speaking. & 1 & 2 & 3 & 4 & 5 \\
\hline 6 & I use the dictionary to prepare some vocabulary for my speaking activity. & 1 & 2 & 3 & 4 & 5 \\
\hline 7 & $\begin{array}{l}\text { I myself practice some formal exercises to improve my pronunciation, listening ability, } \\
\text { relating to speaking ability. }\end{array}$ & 1 & 2 & 3 & 4 & 5 \\
\hline 8 & I repeat silently to myself when someone is speaking English. & 1 & 2 & 3 & 4 & 5 \\
\hline Com & ensation Strategies & & & & & \\
\hline 9 & When I cannot think of a word, I use Vietnamese. & 1 & 2 & 3 & 4 & 5 \\
\hline 10 & When I cannot recollect a word, I use known words/ phrases (i.e. synonyms). & 1 & 2 & 3 & 4 & 5 \\
\hline 11 & When I cannot think of a word, I use gestures. & 1 & 2 & 3 & 4 & 5 \\
\hline 12 & I use either contextual or linguistic clues to understand what is being uttered by others. & 1 & 2 & 3 & 4 & 5 \\
\hline Me & cognitive Strategies & & & & & \\
\hline 13 & Before speaking, I set up a clear goal to push up my motivation. & 1 & 2 & 3 & 4 & 5 \\
\hline 14 & While speaking, I pay attention when someone is speaking English. & 1 & 2 & 3 & 4 & 5 \\
\hline 15 & After speaking, I evaluate how well the task has been done. & 1 & 2 & 3 & 4 & 5 \\
\hline Affe & tive Strategies & & & & & \\
\hline 16 & I try to relax or breathe deeply to reduce anxiety before speaking. & 1 & 2 & 3 & 4 & 5 \\
\hline 17 & Before speaking, I encourage myself that I can finish the speaking task. & 1 & 2 & 3 & 4 & 5 \\
\hline 18 & I share my feeling with my friends to increase my self-confidence. & 1 & 2 & 3 & 4 & 5 \\
\hline Soc & Strategies & & & & & \\
\hline 19 & I ask my partners to repeat a word/phrase if I do not hear it clearly. & 1 & 2 & 3 & 4 & 5 \\
\hline 20 & If I do not know how to say something, I ask a more proficient speaker for help. & 1 & 2 & 3 & 4 & 5 \\
\hline 21 & While speaking, I am aware of others' thoughts to modify my utterances. & 1 & 2 & 3 & 4 & 5 \\
\hline
\end{tabular}

\section{APPENDIX B: SEMI-STRUCTURED INTERVIEW}

Q-1: Do you frequently use memory strategies for your speaking learning? If yes, specify your situation. If no, why?

Q-2: Are you frequently in favor of cognitive strategies for your speaking learning? Specify your response.

Q-3: When you encounter with communication breakdown, do you often employ compensation strategies? If yes, how? If no, why?

Q-4: Do you often exploit metacognitive strategies before, while and after speaking? If yes, specify your situation. If no, explain.

Q-5: Do you frequently incur affective problems in your oral productions? If yes, name them. In fact, what affective strategies do you apply to manage your psychological states in speaking learning?

Q-6: Do you often ask for clarification or cooperate with peers to accomplish speaking tasks? In yes, specify your case. If no, explain. 